\title{
Carbon Storage Potential of Forest Land: A Comparative Study of Cases in Finland and Croatia
}

Martina Tijardović

Croatian Forest Research Institute

Jastrebarsko, Croatia

martinat@sumins.hr

Sanja Perić

Croatian Forest Research Institute

Jastrebarsko, Croatia
Jari Parviainen

Finish Forest Research Institute,

Metla Joensuu, Finland

\section{Abstract}

Background and Purpose: The concentrations of greenhouse gases in the atmosphere have been increasing over the last hundred years in relation to the Fourth IPCC assessment report that highlighted human activities as a direct influence on climate changes. Since Croatia and Finland signed the Kyoto Protocol, they are both committed to fulfil international obligations of lowering GHG's emissions, enhancing the storage, as well as protecting and enhancing the current pools where the forestry sector has a prominent role. These obligations created a need for a review on carbon storage potentials for both countries with the aim of setting further scientific and management guidelines as the basic purpose of this research.

Materials and Methods: Data collection was conducted within the scope of the Sort Term Scientific Mission (STSM) in the period from May 2 - July 22, 2009 in the Finnish Forest Research Institute in Joensuu. The research encompassed an overview of literature, personal contacts with scientists and experts from both countries (research institutes, ministries, the EFI branch office in Joensuu) and a field inspection which altogether provided an insight into the applied silvicultural and utilization activities. A significant data source were official documents and published project results on the carbon storage potential.

Results and Discussion: Mitigation activities within the framework of the LULUCF project reduced the total emissions for 33.4 millions tons of $\mathrm{CO}_{2}$ equivalents in Finland in 2006 (this data has varied from 18 to 33.4 millions tons $\mathrm{CO}$ equivalents in the last fifteen years) while for Croatia the availability of such data is limited. Finland has some former agricultural land which may be afforested but not in the substantial share, while in Croatia such areas amount to around 1 million ha. According to the climate change scenario for Finland (FINADAPT), predicting the largest climate changes, the total forest growth nationwide is estimated to increase by $44 \%$ which will have positive impact on the forest carbon storage in the future. In Croatia there is no such kind of research. There is about $12.6 \%$ of all forest land in Finland under protected forests (strictly protected areas about $3.6 \%)$ in which enhancement of carbon storage potential may be enhanced. About $21 \%$ of the forests in Croatia (513 155 ha) are forests in some degradation stage in addition to about 500 ha of forests where management is prevented because of the land mines. These areas present a potential for carbon storage enhancement. Forest fires pose a great threat to carbon pools especially in the Croatian karst areas where the total of 251901 ha of the Croatian land area burned in the period 1992-2007, which in average amounts to 15744 ha annually. Nevertheless, Finland and Croatia do not undertake any significant current deforestation activities.

Conclusions: Even though Croatia and Finland have the same goals, they also show significant differences in relation to the already finished, current and planned scientific activities, legislation, implementation, natural conditions and constrains of $\mathrm{CO}_{2}$ sequestration and storage. It is estimated that a significant potential in Finland lies in the reduction of $\mathrm{CO}_{2}$ emissions through substitution effects, protection of stored carbon pools in forest ecosystems, avoiding the changes in land use, etc. Croatia, on the other hand, has a significant potential through afforestation activities on uncovered forest and abandoned agricultural lands. Further research on the categorisation of land, appropriate species and provenances selection is necessary. The effects of individual measures on emission reduction and carbon balance by forests are small on the national, as well as on the European scale, but if combined together the overall effects present a great potential to fulfill international obligations in both countries.

Keywords: Kyoto Protocol commitments, natural conditions, legislation, silvicultural activities, land use change. 


\section{INTRODUCTION}

The concentrations of greenhouse gases (GHGs) in the atmosphere have increased over the last hundred years. According to the Fourth IPCC assessment report [1] the concentrations of the GHGs, e.g. carbon dioxide $\left(\mathrm{CO}_{2}\right)$, methane $\left(\mathrm{CH}_{4}\right)$, nitrous oxide $\left(\mathrm{N}_{2} \mathrm{O}\right)$, ozone and halogenated hydrocarbons ( $\mathrm{F}$ gases) in the atmosphere have increased over the last hundred years. The GHGs are gaseous constituents of the atmosphere, both natural and anthropogenic, that absorb and emit radiation at specific wavelengths within the spectrum of the infrared radiation emitted by the Earth's surface, atmosphere and clouds. In this way greenhouse gases prevent heat from radiating back into space, as a consequence of which they cause the greenhouse effect (global warming). According to the IPCC 2007 report [1], human activities were highlighted as a direct influence on climate change and the current scientific knowledge confirms that forests may reduce the concentration of $\mathrm{CO}_{2}$ in the atmosphere and therefore mitigate climate changes [1-6]. According to Goodale et al. [7], forests in the northern hemisphere (Canada, United States, Europe, Russia, China) provided a total sink for $0,6-0,7 \mathrm{Pg}$ of $C$ per year $\left(1 \mathrm{Pg}=10^{15} \mathrm{~g}\right)$ during the early $1990 \mathrm{~s}$. The internationally accepted definition of mitigation states is that they are anthropogenic interventions to reduce the anthropogenic forcing of the climate system [1]. They include strategies to reduce GHGs sources and emissions, as well as enhancing GHGs sinks. According to the Protocol agreed upon at the Third UNFCCC (United Nations Framework Convention on Climate Change) in Kyoto [8], industrial economies and economies in transition are committed to reduce their collective emissions in 2008-2012 to 5\% below the levels of 1990.

Finland and Croatia signed the Kyoto Protocol, but their ratification and implementation in legislative and forest management is quite different. The human influence on forests in both countries has been extensive and it has a long history. In Finland the livelihood and cultural development of humans has been more dependent on forests than anywhere else in Europe. The forest cover in Finland is more extensive than in any other European country. The three fourths of the land area in Finland is covered by forests (some 23 million hectares) [9]. The forest cover in Croatia is about 2.5 million ha [10] and Croatia has about 10 times less forest area per capita then Finland, 79.23 $\mathrm{m}^{3}$ in Croatia and about $412.48 \mathrm{~m}^{3}$ in Finland. About $60 \%$ of Finland's forests are privately-owned, while the situation in Croatia is completely different with about $81 \%$ of state-owned forests [11]. "Metsähallitus" in Finland and "Croatian Forests Ltd" in Croatia manage, use, and protect natural forest resources and other property on the state-owned lands under their administration. In Finland, the function of the 151 Forest Management Associations is to promote the profitability of forestry practiced by forest owners and to support the attainment of objectives they set for their operations. The associations are funded and operated by the forest owners. The Forest Management Associations are organized geographically into Unions of Forest Management Associations (ten unions as of January $1^{\text {st }} 2007$ ). In Croatia, the Forest Advisory Service was established in 2007 and empowered by the Government to advise forest owners, but also to fulfill legal obligations in the management, exploitation and protection of private forests. In 2010, the Croatian Government canceled all activities of the Forest Advisory Service and once again empowered the "Croatian Forests Ltd." to manage private forests, due to the cutting of expenses of government services.

Natural conditions for forest growth in these two countries are quite different which has a direct impact on the possibilities of carbon storage. Croatia lies in the temperate and the Mediterranean zone, while Finland is situated in the boreal zone. Therefore, the conditions for forest growth are completely different, nevertheless, both countries have specific areas with large limitations for forest growth. Owing to the conditions in the north, forest management in Finland takes place in climatically exceptional conditions because of the low temperature and high precipitation [12]. Geographically, Finland lies in the intermediate zone between the maritime and continental climates, belonging mostly to the boreal vegetation zone. Because Finland is over $1.100 \mathrm{~km}$ long on the north-south axis, the conditions for growth vary considerably between the southern and northern parts of the country. Croatia has also very different conditions for forest growth, from the lowland regions with the temperate climate, mountains and hilly regions, to the Mediterranean part with specific climate limitations, such as low precipitation in the vegetation period, high temperatures and high risks of natural disturbances. The impacts of climate changes on the forest cover in Europe and its ability to store carbon dioxide are at the moment well-discussed at international conferences and addressed by numerous international projects. Climate changes have a different impact on both countries with estimations that the impact is to be more severe in Croatia due to the already harsh conditions of high temperatures and drought periods in the Mediterranean part (e.g. Joensuu Forestry Networking Week, 2009).

Even though there are specific differences between these two countries, both countries have the same goals to meet their international obligations, in the 
first place the Kyoto Protocol, but also other EU and UN obligations related to specific mitigation and adaptation issues. Within the scope of those obligations, both countries should try to enhance carbon sequestration if possible and preserve and enhance current carbon pools through their activities. There are several different ways to achieve the goals of mitigation through forestry and the forestbased sector. The first is the mitigation through carbon dioxide storage in forest lands, and through the active management of forests by increasing the sequestration capacity of wooden biomass. The second encompasses the reduction of carbon dioxide emissions through, for example, forest wood products. Emissions trading, according to Article 17 of the Kyoto Protocol, allows countries that have extra emission units to sell this excess capacity to countries that exceed their targets. Each carbon credit, known as a Certified Emission Reduction (CER), represents a ton of carbon dioxide, or an equivalent, not emitted other greenhouse gas [8].

The potential of forests to mitigate climate changes is defined within the framework of the LULUCF project (land-use, land-use change and forestry) [13]. It encompasses afforestation, reforestation and different silvicultural practices which enhance carbon sequestration by forests (e.g. an increase in the growing stock and its influence on carbon storage in the soil). "Afforestation" according to the definition of UNFCC [14] is the direct, human-induced conversion of lands not forested for a period of at least 50 years to forested lands by planting, seeding and/or the human-induced promotion of natural seed sources. "Reforestation" [14] is the direct, human-induced conversion of non-forested lands to forested lands by planting, seeding and/or the human-induced promotion of natural seed sources, on lands previously forested but converted to nonforested lands. Those mitigation activities in Finland reduced the total emissions for 33.4 millions tons of $\mathrm{CO}_{2}$ equivalents in 2006. This number has varied in the last fifteen years from 18 to 33.4 millions tons $\mathrm{CO}_{2}$ equivalents. For Croatia, the availability of this kind of data is rather limited.

Within the scope of the LULUCF project, the avoiding of the change of land use on the global scale refers mainly to deforestation activities. Forest fires also pose a great threat to climate change mitigation since they release the stored carbon into the atmosphere and reduce carbon stocks in the living biomass. In relation to different intensities of wild forest fires, there are more and less dangerous fires which have to be taken into account. Some forest fires may influence the forest's ability to regenerate which causes the total devastation of the burned area. These already mentioned national and international obligations created a need for a review of the carbon storage potentials for both countries with the aim of setting further scientific and management guidelines as the basic purpose of this research.

\section{MATERIALS AND METHODS}

Since the options and potentials for climate change mitigation depend on local circumstances and specific issues, the need arose within the scope of the COST Action ECHOES (Expected Climate Change and Options for European Silviculture, Working Group III: Mitigation) to investigate differences and possible similarities of the potentials for climate change mitigation in Finland and Croatia. The research was conducted within the scope of the Sort Term Scientific Mission (STSM) in the period from May 2 July 22, 2009 in the Finnish Forest Research Institute in Joensuu. This international cooperation was based on the mitigation potential comparison together with political, legislation and management implementation issues and, therefore, presents the basis for creating a COST database on the potentials of forests and forest products in Europe to mitigate climate change. The research encompassed an overview of literature, personal contacts with scientists and experts from both countries (research institutes, ministries, the EFI branch office in Joensuu) joined with a field inspection, which altogether provided an insight into the applied silvicultural and utilization activities. A significant data source were official documents and results of the published project on the carbon storage potential.

\section{RESULTS AND DISCUSSION}

\section{Historical Circumstances, Current Legislation and Associated Projects}

The Kyoto Protocol, besides committing industrial economies and economies in transition to reduce their collective emissions to five percent below the levels of 1990 in 2008-2012 [1], also obliges them to implement the containing measures to mitigate climate change into their policies national programmes by addressing the sources and removals by sinks. Furthermore, they have to promote the processes that control, reduce or prevent emissions of GHGs in relevant sectors and promote sustainable management, conservation and enhancement of sinks and reservoirs, including biomass, forests and oceans, as well as other terrestrial, coastal and marine ecosystems.

\section{Finland}

In Finland, the Ministry of Environment is in charge of the matters related to the UN's Framework 
Convention on Climate Change (UNFCCC) and international negotiations under the Convention [9]. Several national expert teams were nominated to facilitate the negotiation and the reporting process. The Finnish statements to the climate negotiations were prepared under the "Climate Work Group" and the "Gas Work Group", nominated by the Ministry of Environment which is responsible for the Finland's Annual Inventory Report on GHGs submitted to the UNFCCC [15-17]. Finland's National Strategy for Adaptation to Climate Change was completed in 2005. The Strategy described, among other things, the impacts of climate changes on forestry and outlined measures to be implemented in the forest management. On the basis of the Strategy, the research program on the adaptation to climate change, called ISTO (Climate Change Adaptation Research Programme) was launched in 2006 [18, 19].

In Finland, according to Karjalainen and Mäkipää [15], the national reporting of GHG inventories for changes of land-use and forestry category utilizes forest inventory results with appropriate studies on the allocation of biomass and wood properties, as well as the national wood consumption statistics allowing the use of country-specific values instead of overall default values provided in the IPCC guidelines. Several studies assessing carbon stocks and fluxes, as well as the impacts of forest management on carbon stocks and fluxes, were carried out in several research organizations. Besides the already mentioned annual national reports under the UNFCCC, there is an immense amount of literature related to climate change mitigation in Finland [20-30].

\section{Croatia}

The situation in Croatia is quite different from the situation in Finland. In Croatia, the Ministry of Environmental Protection, Physical Planning and Construction is in charge of the international negotiations under the UNFCCC [31]. Even though Croatia signed the Kyoto Protocol in 1990, the document was not ratified until May 2007, after long and hard negotiations to assure an equal position as all other European countries. As a result of specific circumstances related to the war in Croatia, the initiation of the Kyoto related activities in legislative and political terms, together with its implementation in Croatia, was delayed in relation to other countries. In February 2002, Croatia issued its first National Report on greenhouse gas emissions for the UNFCCC, followed by others [32, 33]. The Ministry has recently published the National Strategy for the Implementation of the Framework Convention on Climate Change (UNFCCC) and the Kyoto Protocol in the Republic of Croatia with an action plan [31]. This
Strategy was published on the basis of the Project LIFE04 TCY/CRO/029: "Capacity Buildingfor the Implementation of the United Nations Framework Convention on Climate Change and the Kyoto Protocol in the Republic of Croatia". There are several projects related to climate change issues conducted within the scope of the Ministry of Environmental Protection, Physical Planning and Construction and several other scientific institutions in Croatia.

For example, "Expedited Financing of Climate Change Enabling Activity - Phase II (CRO/03/G31/ A/1G/99)" [31]; "UNDP/GEF Capacity Building for Improving the Quality of Greenhouse Gas Inventories (Europe/CIS region)" [31]. With the above mentioned documents the Ministry provided the base for addressing climate change mitigation in Croatia.

Studies related to carbon storage in Croatia were conducted within the scope of the activities by the Croatian Forest Research Institute (projects lead by $\mathrm{H}$. Marjanović: The Sustainability of Carbon Storage in the Managed Pedunculate Oak Forests; Enhancement of the Information System "HŠ Fond" with a Module for Monitoring and Recording Carbon Forest Storage" HŠ-Fond-Carbon"). The studies assessing carbon stocks and fluxes, as well as the impacts of forest management on carbon stocks and fluxes were carried out within the scope of activities of the Croatian Forest Research Institute [34, 35].

In Croatia, the literature related to this kind of research is rather limited due to the fact that most research is still in progress and only some results were published [33, 34, 35, 37]. Papers published up to now are more related to the production of the biomass of different alohtonous and autochtonous species in various bioclimates in Croatia [38, 39].

\section{Afforestation Activities}

In Article 3.3 of the Kyoto Protocol [8], the UN stated that carbon sequestration after afforestation may be accounted as a sink in the national GHG budgets. Therefore, these activities present a possible solution in the GHG emission reduction for many countries [40].

\section{Finland}

Small amounts of potential areas for afforestation in Finland, together with complex issues of the transformation of peat into the forest soil, limit these activities and significantly influence its carbon balance ( $\mathrm{H}$. Peltola, unpublished data). Finland has got a certain amount of former agricultural land to be afforested within the scope of the LULUCF activities, but not in the substantial share which would make 
it significant as a carbon sequestration potential on the national level. Most of the abandoned agricultural land suitable for afforestation in Finland are former peat land areas, and those have mostly been afforested by now so they present no actual sequestration potential (Heli Peltola, unpublished data). Nevertheless, there is a certain controversy about the afforested peat land areas since they may increase carbon emissions in relation to the original peat lands, but lower methane emissions. In that way, they may have a positive impact on the reduction of GHG emissions [40] but its share in the total GHG balance for Finland would probably not be significant.

The significance for afforestation and reforestation of other uncovered lands in Finland is low in terms of climate change mitigation. Finland has the largest share of the forest cover in the whole Europe (three thirds). There are some areas (the Lapland area) where, by means of natural succession induced by changed climatic conditions, the tree limit is shifting further towards the north. Those areas have a large biodiversity and a low share in the total country area, therefore, specific activities should be applied to prevent the tree limit shifting [19]. There are also 3.2 million ha of wasteland in Finland, but the capability to produce volume increment on those areas is low (less than $0.1 \mathrm{~m}^{3} \mathrm{ha}^{-1}$ year ${ }^{-1}$ ) so those areas have no significant potential for climate change mitigation through afforestation. There are current research activities, for example, in the Mekrijärvi research station of the University of Eastern Finland, about the potential of biomass production with reed canary grass on drained peat lands and the influence on carbon emissions from peat, but such activities do not belong to the forestry sector.

\section{Croatia}

Available areas for afforestation in Croatia are subjects of rough estimation. They amount to around 1 million ha, which, in comparison with the total of 2688687 ha of forests and forest land, clearly shows the importance of the afforestation potential and possibilities for Croatia [42]. Croatia has a bigger potential for mitigation through afforestation of abandoned agricultural lands in relation to its land area than Finland. Some of the Management units in private forests have already been substantially enlarged by areas left to natural succession (abandoned agricultural lands). The exact size of these areas will be known after the completion of the new management plans for private forests, but evidently those areas are growing constantly. The problem is that the afforestaton of those areas is expensive and there are no current subsidies in Croatia for afforestation activities.
Therefore, many of those areas are in some stage of degradation waiting for the management to take effect. The current management plans incorporate some traditional management activities for the spontaneously afforested areas through natural succession, but climate change mitigation or adaptation measures were not implemented. Also, those areas are in different bioclimates in Croatia with different volume production capacities (e.g. high in lowland areas and rather low in the Mediterranean region), so if the true potential of these areas is to be known, there should be more scientific research on this matter, especially in the Mediterranean region.

On the other hand, there are 208467 ha of available uncovered forest land for afforestation activities in Croatia [11] which is a significant area. This land has a different share in separate regions of Croatia with different production capacities and, therefore, different potentials for climate change mitigation. In this case, as well as in the case of the afforestation of former agricultural land, there is no current data on sequestration expected in those areas since there is no current data on the soil sequestration and the potential productivity on separate sites (carbon storage may be estimated through the potential of wood production on separate sites). The project "Preservation of Stability and Productive Ability of Forest Cultures" (Perić and Tijardović, within the Ministry of Science, Education and Sport) deals with the issue of establishing and producing forest cultures throughout Croatia. Also, two ongoing projects (2011-2013) conducted under the auspice of the "Croatian Forests Ltd" (Perić and Tijardović) deal with afforestation activities and the potential production in the continental part of Croatia ("Afforestation of Karst Wasteland in the Lika Region" and "Management of Forest Cultures in Croatia with a Special Attention on the Conversion Activities"). There are some estimations of carbon sequestration within the scope of the UNFCCC national reports, but there should be more research to gain more reliable and more accurate estimations (especially for specific regions). Nevertheless, carbon sequestration in the soil currently presents a gap in the scientific knowledge in Croatia and therefore it requires more scientific research on this matter. The presented information is related only to the uncovered state-owned forest areas, while the precise size of privately-owned wasteland areas is still unknown. There may be some potential in forest lands in private ownership in Croatia as well, because there are many unsuccessfully naturally regenerated areas which were left to natural succession in the past (their current state in most cases is some degradation stage, which may potentially provide more benefits for the carbon balance on 
the national level), but more detailed data will be available after the completion of management plans. In addition, there are special issues which have not yet been investigated, regarding some areas in the Croatian mountain region where pastures have been overtaken by forests of autochthonous tree species (Picea abies) through the process of natural succession. In those areas the carbon pool in the soil would be decreased [43], but also the carbon sequestration through biomass production may benefit climate mitigation. But, this process raises the issue of acceptability from the point of gaining carbon credits, because pastures are usually not managed (private lands with questionable ownership). In addition, succession processes may induce a decrease in the biodiversity and therefore be contradictory to the UN's Convention on Biological diversity [44] and guidelines of the IUCN for afforestation and reforestation for climate change mitigation. If those areas may officially be converted to forests in order to gain carbon credits and wood certificates, how much that would participate in the total potential for mitigation in Croatia remains an open question for further research. There is no current data about the size of those areas, but it may be substantial (e.g. Lika and Gorski Kotar). Therefore, further research is needed if those areas are to be considered as potentials for mitigation.

\section{Forest Extension Services}

One of the main problems in both countries is that basically it is the responsibility of the forest owner to implement those activities into their management. For Finland, it represents an important issue due to a high share of private forests. In Croatia, a large gap in the knowledge about climate changes and adaptation or mitigation activities is currently present among forest managers or private forest owners. The subsidies and education on climate change and mitigation was planned to be implemented into the actions of the Croatian Forest Advisory Service. Currently, workshops organized within the framework of the Low-Emission Development Strategy (LEDS) are the only available education on climate change issues for forest managers or policy-makers. The administrative period of transferring the activities from the "Forest Advisory Service" to the "Croatian Forests Ltd" was a period with no involvement of private forest owners in mitigation and adaptation activities. In Finland, there are no current national subsidies for afforestation activities (excluding the EU financing in some special cases). The education of private forest owners is done within the scope of the activities by the Forest Management Associations. Education of private forest owners and subsidies are probably the only way to persuade private forest owners to afforestate their land.
In addition, there should be more scientific research on these issues in both countries, especially Croatia, and the results should be incorporated by educating forest officers, regardless of whether they work in privately- or state-owned forests. There may be a big potential in Croatia for mitigation by establishing energy plantations and cultures for biomass production, but this issue is heavily influenced by the entire chain of biomass production, not yet successfully established in Croatia. Nevertheless, these activities may have a significant negative impact on biodiversity which has to be taken into account [45].

\section{Changes in Carbon Storage in Soil after Afforestation}

\section{Finland}

Extensive research has been done up to now and a lot of publications are available in Finland in relation to the influence of carbon storage in the soil after afforestation, especially on drained peat land areas [46-51]. Also, extensive research was done on carbon storage in the soil with various stand ages, species composition and predictions of climate changes [5256]. After afforestation and preceding the drainage of the peat land, it becomes a source of carbon. Nevertheless, in relation to the produced woody biomass and related to carbon storage together with a reduction of methane and nitrous dioxide emissions, there may be a positive effect in some locations. In accordance with the papers published by the International Peat Society $[45,57]$ the maintenance of large stores of carbon on undisturbed peat lands should be a priority, but it was also stated that due to changes in the climate, those areas might become drier and therefore emit more carbon dioxide into the atmosphere. The remaining question in this matter is the uncertainty of climate predictions together with the size of those areas in the future and their suitability for afforestation in relation to natural succession and biodiversity.

In case of mineral soils, the temporary reduction of soil carbon storage after afforestation is not so significant since there is a great carbon storage in forest products which are suitable to substitute fossil fuels and many other materials. Since the period of afforestation of the former agricultural land is presumably over in Finland, this presents an issue of a lesser significance for Finland.

\section{Croatia}

For Croatia there is no currently available literature to cover the issues of afforestation influencing carbon storage in the soil. There is an ongoing project regarding the carbon balance of pedunculate oak in the lowland region of the river Kupa within 
the scope of determining carbon storage in the soil (Marjanović 2011-2013). The research on the change of carbon storage in Croatian acid soils, covered by Pteridium and Calluna species, after afforestation with different species, would provide more accurate data than the current estimations for other soils. Such results would present a valuable contribution on the carbon sequestration potential of those areas since these represent a significant part of the area available for afforestation in central Croatia with a good production capacity. Also, the research on the influence of afforestation in different soil types throughout Croatia and the conversion and substitution of tree species on carbon storage in the soil, may be interesting in relation to the changes in the soil $\mathrm{C}$ pool.

\section{Enhancement of Forest Sequestration through Silvicultural Measures}

\section{Finland}

The potential of forests to store carbon varies in relation to climate changes [56, 57]. According to the climate change scenario for Finland (FINADAPT), given the largest climate changes [60], the total forest growth nationwide is estimated to increase by $44 \%$ which will have a positive impact on the forest carbon storage in the future. Nevertheless, a high uncertainty in climate change prediction has to be emphasized and adaptation measures more investigated. The second issue related to silvicultural measures is concerning protected forests. There is a share of about $12.6 \%$ of all forests and forest lands in Finland under protection. Strictly protected areas have a share of about 3.6\% [19]. In accordance with the Opinion of the European Economic and Social Committee on the role of forests and the forest-based sector at the meeting of the EU's climate commitments [61], there is an important difference between commercial forests and natural forests in terms of carbon sequestration. From the perspective of climate protection, natural forests in their equilibrium state represent a carbon sink, where carbon sequestration through the growth of biomass and carbon release through decay of biomass are in balance. On the other hand, commercial forests are constantly developing new and additional carbon sequestration capacities due to the harvesting of timber. So, this strong evidence opens the question of the high share of protected forests in Finland in relation to mitigation. The question of natural regeneration of protected forests due to changed climatic conditions is also relevant because the implementation of adaptation measures in those areas is prevented.

Forests in Finland are mainly already continuously extensively managed so there are no possibilities to enhance carbon sequestration other than applying fertilization with the aim to enhance production or establishing new stands only with the selected genetic material which may enhance wood production by 20 $30 \%$ in relation to the unselected planting material (Heli Peltola, unpublished data). The increased use of small-sized trees for bioenergy purposes, obtained by tending measures in young forests, have improved the profitability of management and developed an interest to take care of this less profitable management phase of stands. In the last several years there has been a significant decrease in pulp and paper production in Finland [62]. The issue was raised of temporarily stopped thinnings which may lower the sequestration rate (exp. in private forests) and possibly have a negative effect on the position of pulp and paper industry in the future. But, currently there are activities on the interconnection between pulp and bio-fuel industry in Finland, so there may be a small influence of this crisis on $C$ sequestration in the future.

There are many issues on the implementation of mitigation activities in private forests, especially in Finland, since the biggest share are private forests. One of the difficulties is the joined ownership of descendants after the death of previous owners. A larger number of private owners and the decreased average area of private forest add difficulties to the implementation of appropriate measures. In addition there are large areas of private forests in Croatia which have not been properly managed (e. g. during the war) those areas may become significant carbon sinks through the implementation of proper silvicultural activities and the education of forest advisors and forest owners.

\section{Croatia}

The share of strictly protected forests in Croatia is lower than in Finland $\left(5.605 \mathrm{~km}^{2}\right.$ or $9.9 \%$ of the land area according to the Law on Nature Protection) [18]. Nevertheless, according to the Forest Management Plan for Croatia [63], 84\% of all forest areas are managed forests with a commercial function, but the remaining $16 \%$ are forests with protective and special functions where only salvage cutting is allowed. This kind of management makes those forests high risk forests so the same issues may be relevant for Croatia in relation to mitigation potentials.

This question is even more opened for discussion and further research because some of these areas are in the Mediterranean region and therefore subjected to high risks of fires (carbon storage in forests subjected to natural disturbances is questionable) and strong projected influence from drought due to 
the changing climate (also questionably protected function in the future).

The share of high forests in Croatia is about $54 \%$ of all covered areas (1 $283561 \mathrm{ha}$ ) where silvicultural treatments are conducted for the production of high quality technical wood on the basis of natural principles (the Quercus robur forests in the Slavonia region), so there is no possibilities to enhance carbon sequestration (the potential) through silvicultural measures unless the stability of forests or quality of products is reduced. But about $21 \%$ of all forests in Croatia (513 155 ha) are forests in some degradation stage (garrigue $1 \%$, maquise $2 \%$, shrub $18 \%$ ), where commercial exploitation is not financially interesting, so those areas may have a substantial potential for mitigation. Their carbon storage is low, but if those areas should be converted to high forests for timber production (on sites where the site conditions allow it) or they be used for biomass production, their carbon storage potential may be much higher. Since some of these areas are in the Mediterranean region under a high risk of fires, exploitation for biomass may present a possibility for reducing fire risks. Within the scope of climate adaptation, the only way of reducing fuel in the Mediterranean forests, and thus reducing the risks of fire ignition and fire intensities, would be to render those forest financially interesting [64]. Without any further research on the distribution of this kind of forests (different bioclimates provide different volume production potentials), it is almost impossible to make any kind of estimation. There should be further scientific research on the policy and legal reimbursement of those measures which currently do not exist in Croatia. Further research about the sequestration in forest soils, as well as in the wood biomass, in those areas is also needed.

In addition, there are about $3 \%$ of forest cultures in Croatia about 40 to 60 years old and where none or very little management has been done due to different social reasons. They are currently included in the ongoing project about the best ways for silvicultural practices and management of those cultures from the economical point of view and with a special overview on climate change adaptation measures (Perić and Tijardović Management of Conifer Cultures in Croatia 20112013). Those areas may have some potential for mitigation, but more research on this matter is required.

In addition, there are about 500 ha of Croatian forests where management is prevented because of the land mines from the war in Croatia [65]. This area is not significant, but the question was raised due to carbon storage and its sensitivity to natural disturbances (e. g. forest productivity and carbon storage may be lost due to windthrow or decreased because of the lack of silvicultural measures).

\section{Influence of Wildfire Behavior on Carbon Storage}

\section{Finland}

Due to efficient monitoring and favorable natural conditions, such as high precipitation and lower summer temperatures in Finland, forest fires have remained extremely rare although there are several hundred fires each year. So, for Finland this is not an important issue for mitigation even though changes in climate may increase plausible conditions for the occurrence of fire.

\section{Croatia}

On the other hand, forest fires pose a great threat in Croatia, especially in the karst area where 3678 forest fires occurred in the period 1992-2007, 4851 fires in total in the whole country [66]. In the same period, 251901 ha of Croatian land area was burned, which in average amounts to 15744 ha annually. The only possible way that the risks of fires may significantly be reduced, besides monitoring, is if those forests would become economically efficient, for example through the substitution of biomass which is important for mitigation. Therefore, this may be a great mitigation possibility for Croatia and further research is needed since this depends on the entire chain of biomass production.

\section{Avoided Changes in Land Use}

\section{Finland}

Changes in land use may have a significant impact on the decrease of carbon storage if deforestation activities are taken into account. In both countries, Finland and Croatia, there are no significant current deforestation activities. Finland and the Finnish people have always had a strong connection with peat lands, since there is about 10.4 million ha of peat lands in Finland (one third of the whole land area). About 5.7 million ha of peat land is currently used in forestry [57]. But, there are many issues related to peat lands, as mentioned already, since drained peat lands may emit carbon dioxide. Natural, undrained peat lands produce methane emissions, and agricultural lands with the highest nitrous oxide emissions produce the most GHG emissions. The afforested drained peat lands and the afforested former agricultural peat lands may have a positive balance of GHG emissions, but that depends on specific site conditions (i.e. soil water, temperature). Also, the changing climate may have an effect on peat lands in diverse ways. For instance, warming may move the area of the raised bogs northwards, 
which in turn may result in an increase of the total accumulation of carbon in northern peat lands, but perhaps decrease the rate in southern mires due to accelerated decomposition [57]. In terms of GHG management, the maintenance of large stores of $C$ in undisturbed peat lands should be a priority [45]. Therefore, this presents an important issue for Finland forestry and mitigation, especially in the future. However, there are available publications which address the issues of peat land in the conditions of the changing climate [e.g. 45, 66, 67] and those for Finland in particular $[21,57,68]$.

\section{Croatia}

Peat lands in Croatia do not have much influence on the total carbon balance for the whole country since there are only $26 \mathrm{~km}^{2}$ of peat lands in Croatia [32, 33]. There may be some more not registered peat land areas, since they were converted into the agricultural lands.

There is the question of changing the use of land,from agricultural to forest biomass production sites. If the sustainability criteria for biofuels is to be included into the Directive of Green Public Procurement, these issues certainly have to be addressed there [9]. Also, Croatia has swamps as natural GHG sources. Even though those areas are not substantial for GHG emissions for Croatia in general, their emission may change due to climate changes (i.e. higher temperatures and less precipitation). Most of those areas are protected due to the conservation of natural diversity.

Exploitationareas (e.g.queriesin Croatia, peatutilization in Finland) and the questions of their revitalization are important from the aspect of the changing climate condition, the occurrence of extreme events and consequently more problematic revitalizations in those areas (i.e. preserving carbon balance on deforested area and assuring its stability after revitalization). But, it has a low influence on the total carbon balance on the national level, since at the moment there are no other significant changes of land use.

\section{CONCLUSIONS}

On the basis of the international experience and knowledge exchange, several conclusions may be drawn. The available areas for afforestation in Croatia are important for the total carbon balance in Croatia, but there is no substantial quantity of such areas in Finland. Croatia has a significant potential for the emission reduction on the national level through the afforestation of the abandoned agricultural lands and, therefore, more attention should be given to these issues. In Finland there have been no changes in the forest area during the last 50 years.
In relation to the risk from natural disturbances, it is important to highlight that this issue is present in Finland's forestry, but has an even more importance for Croatia (especially in the Mediterranean area), so more attention should be given to research and the application of carbon storage preservation activities.

Protected forest areas are currently in carbon balance, but commercial forests are always acting as carbon sinks (due to the wood substitution effect), so it is important to raise the question of the size of protected areas, especially for Finland, where this question is not addressed at the moment.

There is a great importance of the implementation of mitigation measures into management forest plans on the local scale for both countries, as well as the education of forest managers and forest owners on the possibilities of carbon reduction through the forestry sector.

The final and the most important conclusion is that the effects of some individual measures to enhance the storage of carbon dioxide in forests is small on the national, as well as on the European scale. Nevertheless, by fullfilling of all the above mentioned individual potentials, together with the implementation of carbon emission reduction measures, their combined effect is of a great importance not only for carbon balance in both countries, but also on the European scale. Therefore, more effort should be made on the political, legislative, scientific and implementation basis in both countries, especially in Croatia. The education of forest managers and private forest owners on climate change dynamics, further possible impact of climate changes on human lives and the importance of forests and the forestry-based sector in climate change mitigation is important to meet international obligations and fight the current climate changes, as well as those in the near future.

\section{Acknowledgments}

We would like to take this opportunity to thank the scientific board of the international COST project FP 0703: ECHOES for their financial support, as well as the scientists in the Finnish Forest Research Institute and the EFI branch office in Joensuu who acted as hosts for this STSM. Special thanks to Ivan Pilaš, $\mathrm{PhD}$, from the Croatian Forest Research Institute (the Croatian representative in the Member Committee) for supporting and recognizing the need for this kind of research and experience exchange, which is especially important for Croatia where the scientific basis, legislation and implementation of climate change mitigation measures are rather limited at this point. 


\section{REFERENCES}

1. INTERGOVERNMENTAL PANEL ON CLIMATE CHANGE 2007 Fourth Assessment Report. Available at: www.ipcc.ch (Accessed: 15 August 2011)

2. MYNENI R B, DONG J C, TUCKER J, KAUFMANN R K, KAUPPI $P$ E, LISKI J, ZHOU L, ALEXEYEV V, HUGHES M K 2001 A large carbon sink in woody biomass of Northern forests. Proc Natl Acad Sci USA 98 (26): 14784-14789

3. LUYSSAERT $S$, SCHULZE $E$ D, BORNER $A$, KNOHL $A$, HESSENMOLLER D, LAW B E, CIAIS P, GRACE J 2008 Oldgrowth forests as global carbon sinks. Nature 455 (7210): 213-215

4. GORTE R W 2009 Carbon sequestration in forests. CRS Report for Congress, Congressional Research Service. Available at: www.crs.gov (Accessed: 15 August 2011)

5. LAITAT É, KARJALAINEN T, LOUSTAU D, LINDNER M 2000 Contribution of forests and forestry to mitigate greenhouse effects. Biotechnol Agron Soc Environ 4 (4): 241-251

6. LISKI J, KARJALAINEN T, PUSSINEN A, NABUURS G J, KAUPPI $P 2000$ Trees as carbon sinks and sources in the European Union. Environ Sci Policy 3 (2-3): 91-97

7. GOODALE $C L$, APPS M J, BIRDSEY R A, FIELD C B, HEATH L S, HOUGHTON R A, JENKINS J C, KOHLMAIER G H, KURZ W, LIU S, NABUURS G J, NILSSON S, SHVIDENKO A Z 2002 Forest carbon sinks in the northern hemisphere. Ecological Society of America, Ecological Applications 2 (3): 891-899

8. UNITED NATION CONVENTION ON CLIMATE CHANGE, Kyoto, $11^{\text {th }}$ December 1997. Available at: http://unfccc. int/kyoto_protocol/items/2830.php (Accessed: 25 August 2011)

9. PARVIAINEN J, VÄSTILÄ S, SUOMINEM S 2009 Finnish forest and forest management. In: Parviainen J. Vapaavuori E. Mäkelä A (eds) 2009 COST Action FP0703-ECHOES: country report Finland

10. CROATIAN FORESTS LTD Official website. Available at: www.hrsume.hr (Accessed: 15 August 2011)

11. MINISTRY OF REGIONAL DEVELOPMENT, FORESTRY AND WATER MANAGEMENT 2006 Forest management plan for Croatia 2006-2015

12. MINISTRY OF AGRICULTURE AND FORESTRY 2008 Yearbook of Finland's forests, Finland

13. UNITED NATIONS FRAMEWORK CONVENTION ON CLIMATE CHANGE official website. Available at: http://unfccc.int/ methods/lulucf/items/3060.php (Accessed: 29 June 2013)

14. UNITED NATIONS FRAMEWORK CONVENTION ON CLIMATE CHANGE, 2002 Land use, land-use change and forestry: definitions and modalities for Including afforestation and reforestation activities under article 12 of the Kyoto protocol. Available at:http://unfccc.int/meetings/ workshops/other_meetings/items/1082.php (Accessed: 29 June 2013)

15. KARJALAINEN T, MÄKIPÄÄ R 2000 Contribution of forests and forestry in Finland to mitigate greenhouse effect. Biotechno Agron Soc Environ 4 (4): 275-280

16. MINISTRY OF ENVIRONMENT 1995 Finland's national report under the United Nation's framework convention on climate change

17. MINISTRY OF ENVIRONMENT 1997 Finland's second report under the framework convention on climate change

18. PARVIAINEN J, VÄSTILÄ S, SUOMINEM S (eds) 2007 State of Finlands Forests 2007. Available at: www.metla.fi/julkaisut/ muut/state-of-finlands-forests.pdf (Accessed: 23 August 2011)
19. MINISTRY OF AGRICULTURE AND FORESTRY 2007 State of Finland's Forests 2007

20. VAPAAVUORI E, HENTTONEN M, PELTOLA H, MIELIKÄINEN K, NEUVONEN S, HANTULA J, MULLER M 2009 Climate change impact "hot spots" in Finland: Impacts and most susceptible regions of severe impact. In: Parviainen J. Vapaavuori E. Mäkelä A (eds) 2009 COST Action FP0703-ECHOES: country report Finland.

21. KARJALAINEN T, LISKI J, PUSSINEN A, LAPVETELÄINEN T 2000 Sinks in the Kyoto Protocol and considerations for the Nordic countries. Report to the Nordic Ministry Council

22. TOMPPO E 2000 National forest inventory of Finland and its role estimating the carbon balance of forests. Biotechnol Agron Soc Environ 4 (4): 281-284

23. KARJALAINEN T, KELLOMÄKI S 1993 Carbon storage of forest ecosystems in Finland. In: Proceedings of the IPCC AFOS workshop: "Carbon balance of world's forested ecosystemsTowards a global assessment", 11-15 May 1992. Academy of Finland, Joensuu, Finland 3/93: 40-51

24. KARJALAINEN T, PUSSINEN P, KELLOMÄKI S, MÄKIPÄÄ R, 1998 The history and future of carbon sequestration in Finland's forest sector. In: Kohlmaier GH, Weber M, Houghton RA (eds) Carbon dioxide mitigation in forestry and wood industry. Heidelberg, Springer-Verlag, Berlin, pp 25-42

25. KARJALAINEN T, PUSSINEN A, KELLOMÄKI S, MÄKIPÄÄ R 1999 Scenarios for the carbon balance of Finnish forests and wood products. Environ Sci Policy 2: 165-175

26. PUSSINEN A, KARJALAINEN T, KELLOMÄKI S, MÄKIPÄÄ R 1997 Potential contribution of the forest sector to carbon sequestration in Finland. Biomass Bioenergy 13 (6): 377-387

27. MÄKIPÄÄ R, KARJALAINEN T, PUSSINEN A, KELLOMÄKI S 1999 Effects of climate change and nitrogen deposition on the carbon sequestration of a forest ecosystem in the boreal zone. Can J Forest Res 29: 1490-1501

28. MÄKIPÄÄ R, KARJALAINEN T, PUSSINEN A, KUKKOLA M 1998a Effects of nitrogen fertilization on carbon accumulation in boreal forests-Model computations compared with the results of long-term fertilization experiments. Chemosphere 36: $1155-1160$

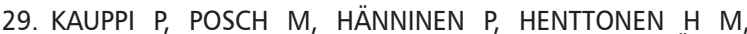
IHALAINEN $A$, LAPPALAINEN $E$, STARR $M$, KELLOMÄKI $S$ VÄISÄNEN $\mathrm{H}$, HÄNNINEN $\mathrm{H}$, KOLSTRÖM T, LAUHANEN R, MATTILA U, PAJARI B 1992 SIMA-A model for forest succession based on the carbon and nitrogen cycles with application to silvicultural management of the forest ecosystems. Joensuun Yliopistopaino Silva Carelica 22: p 85

30. MÄKIPÄÄ R, KARJALAINEN T, PUSSINEN A, KUKKOLA M, KELLOMÄKI S, MÄLKÖNEN E 1998b Applicability of a forest simulation model for estimating effects of nitrogen deposition on a forest ecosystem. Test of the validity of a gap-type model. Forest Ecol Manage 108: 239-250

31. MINISTRY OF ENVIRONMENTAL PROTECTION, PHYSICAL PLANNING AND CONSTRUCTION. Available at: www.mzopu. hr (Accessed: 22 August 2011)

32. MINISTRY OF ENVIRONMENTAL PROTECTION, PHYSICAL PLANNING AND CONSTRUCTION 2006 Second, third and fourth national report to the Framework Convention on Climate Change (UNFCCC) for Croatia. Available at: www. mzopu.hr (Accessed: 22 August 2011)

33. MINISTRY OF ENVIRONMENTAL PROTECTION, PHYSICAL PLANNING AND CONSTRUCTION 2010 Proposition of fifth national report to the Framework Convention on Climate Change (UNFCCC) for Croatia. Available at: www.mzopu.hr (Accessed: 22 August 2011) 
34. MARJANOVIĆ $H$, BENNDORF A, INDIR K, PALADINIĆ E, PERESSOTTI A, SCHWAIGER H, HANNES H, VULETIĆ D 2007 $\mathrm{CO}_{2}$ and Forests in Croatia. In: Local strategies for land use management according to Kyoto Protocol. Available at: http:// bib.irb.hr/ (Accessed: 15 August 2011)

35. MARJANOVIĆ $H$, ALBERTI G, PALADINIĆ E, INDIR K, DELLE VEDOVE G, PERESSOTTI A, VULETIĆ D 2008 One year since the establishment of a research station for intensive monitoring of carbon cycle in a pedunculate oak stand-What have we learnt? In: Matić S, Anić I (eds) Šume hrasta lužnjaka u promijenjenim stanišnim i gospodarskim uvjetima. HAZU, Zagreb, pp 54-56

36. PALADINIĆ E; VULETIĆ D, MARJANOVIĆ H, INDIR K 2009 Evaluation of effects of dry periods on atmospheric carbon storage in young stands of pedunculate oak using $\mathrm{CO}_{2}$ Fix simulator. In: Matić S, Anić I (eds) Šume hrasta lužnjaka u promijenjenim stanišnim i gospodarskim uvjetima. Hrvatska akademija znanosti i umjetnosti, Zagreb, pp 223-238

37. PALADINIĆ E 2009 Estimation of ability of forest stands to sequestrate carbon in the context of Kyoto protocol implementation. Dissertation, Faculty of Forestry, University of Zagreb, 2009

38. ORLIĆ S, KOMLENOVIĆ N, RASTOVSKI P, OCVIREK M 1991 Prvi proredni zahvat, produkcija biomase i njezin kemizam u kulturi obične smreke (Picea abies Karst.) "Velika Buna". Radovi 26 (1-2): 55-64

39. PERIĆ S. ORLIĆ S, IVANKOVIĆ M 2004 Growth of six coniferous species in different bioclimates in Croatia. Ekologia 23 (1): 8698

40. IUCN PROGRAM OFFICE FOR CENTRAL EUROPE 2004 Afforestation and Reforestation for Climate Change Mitigation: Potentials for Pan-European Action. Warsaw, 2004

41. STRACK M (eds) 2008 Peatlands and climate, change. International Peat Society TIJARDOVIĆ M, PERIĆ S 2013 Croatian Norway spruce cultures in European concept of culture management. Periodicum biologorum 2013 - in press.

42. UNITED NATION CONVENTION ON BIOLOGICAL DIVERSITY, Rio de Janeiro, $5^{\text {th }}$ June 1992. Available at: http://treaties.un.org/ Pages/ViewDetails.aspx? src $=$ TREATY\&mtdsg no $=$ XXVII$8 \&$ chapter $=27 \&$ lang $=$ en (Accessed: 23 August 20011)

43. PAUL $K \quad I$, POLGLASE $P$ J, NYAKUENGAMA J $G$, KHANNA P K 2002 Change in soil carbon following afforestation. For Ecol Manage 168 (1-3): 241-257

44. MINKKINEN K, LAINE J 1998 Long-term effect of forest drainage on the peat carbon stores of pine mires in Finland. Can J Forest Res 28: 1267-1275

45. AIVELO T 2010: Forest bioenergy and biodiversity in the EUThe threats, the possibilities and the challenges. Available at: http://www.fern.org/sites/fern.org/files/2010-01\%20 Forest $\% 20$ bioenergy $\% 20$ and $\% 20$ biodiversity $\% 20$ in $\% 20$ the\%20EU.pdf (Accessed: 27 June 2011)

46. YLI-PETÄYS M, LAINE J, VASANDER H, TUITTILA E S 2007 Carbon gas exchange of a re-vegetated cut-away peat land five decades after abandonment. Boreal Env Es 12: 117-190

47. MALANEN M, HYTÖNEN J, MARTIKAINEN P J 2001 Fluxes of $\mathrm{N}_{2} \mathrm{O}, \mathrm{CH}_{4}$ and $\mathrm{CO}_{2}$ on afforested boreal agricultural soils. Plant Soil 231: 113-121

48. MALANEN M, LIIKANEN A, SILVOLA J, MARTIKAINEN P J 2003 Methane fluxes on agricultural and forested boreal organic soils. Soil Use Manage 19: 73-79

49. WALL A, HEISKANEN J 1998 Physical properties of afforested former agricultural peat soils in western Finland. Suo 49: 1-2

50. TAMMINEN P 1997 Carbon reservoirs in peat lands and forests in the boreal regions of Finland. Silva Fennica 31 (1): 13-25
51. LISKI J, ILVESNIEMI H, MÄKELÄ A, WESTMAN C J 1999 CO emissions from soil in response to climatic warming are overestimated-The decomposition of old soil organic matter is tolerant of temperature. Ambio 28 (2): 171-174

52. LISKI J, WESTMAN C J 1997 Carbon storage of forest soil in Finland. 1. Effect of thermo climate. Biogeochemistry 36 (3): 239-260

53. LISKI J, WESTMAN CJ 1997 Carbon storage of forest soil in Finland. 2. Size and regional patterns. Biogeochemistry 36 (3): 261-274

54. LISKI J 1995 Variation in soil organic carbon and thickness of soil horizons within boreal forest stand. Silva Fennica 29(4): 255-266

55. LISKI J, WESTMAN C J 1995 Density of organic carbon in soil at coniferous forest sites in southern Finland. Biogeochemistry 29: 183-197

56. VASANDER H (eds) 1996 Peat lands in Finland. Finnish Peatland Society

57. KARJALAINEN T 1996 Dynamics and potentials of carbon sequestration in managed stands and wood products in Finland under changing climatic conditions. Forest Ecol Manage 80: 113-132

58. KARJALAINEN T 1996 Model computations on sequestration of carbon in managed forests and wood products under changing climatic conditions in Finland. J Environ Manage 47: 311-328

59. KELLOMÄKI S, STRANDMAN $H$, NUUTINEN T, PELTOLA $H$, KORHONEN K T, VÄISÄNEN H' 2005 Adaptation of forest ecosystems, forests and forestry to climate change. FINADAPT WORKING PAPER 4, Finnish Environment Institute Mimeographs Helsinki 334 (44)

60. EUROPEAN ECONOMIC AND SOCIAL COMMITTEE 2009 Opinion on The role of forests and the forest-based sector in meeting the EU's climate commitments.

61. JURJEVIĆ P, VULETIĆ D, GRAČAN J, SELETKOVIĆ N 2009 Šumski požari u Republici Hrvatskoj (1992-2007). Šum list 1-2 (2009): 63-72

62. NISKANEN A 2009: The future strategy of forest-based sector. Presented at conference: Joensuu Forestry Networking Week 2009 Fighting Climate Change: Adapting Forest Policy and Forest Management in Europe. Available at: http:// www.metla.fi/tapahtumat/2009/JFNW2009/Niskanen.pdf (Accessed: 27 June 2011)

63. CROATIAN FORESTS LTD. 2006 Forest management plan 2006 $-2015$.

64. OLABARRIA J R G 2009: Integrating forest fire risk in forest planning. Presented at conference: Joensuu Forestry Networking Week 2009 Fighting Climate Change: Adapting Forest Policy and Forest Management in Europe. Available at:http://www.metla.fi/tapahtumat/2009/JFNW2009/ Gonzales.pdf (Accessed: 27 June 2013)

65. CROATIAN MINE ACTION CENTRE official website. Available at: http://www.hcr.hr/en/ (Accessed: 25 October 2011)

66. TRETTIN C M, JURGENSEN D F, GRIGAL M R, GALE J, JEGLUM $\mathrm{K}$ (eds) 1996 Northern forested wetlands-Ecology and Management. Lewis publishers

67. MÄKIPÄÄ R 1995 Effect of nitrogen input on carbon accumulation of boreal forest soils and ground vegetation. For Ecol Manage 79: 217-226

68. MINISTRY OF AGRICULTURE AND FORESTRY 2007 Greenhouse impacts of the use of peat and peat lands in Finland 
